\title{
PENINGKATAN KUALITAS MADRASAH TERHADAP SISTEM ZONASI MTS NURUL HUDA SEDATI SIDOARJO
}

\author{
Naila Afifa Rohmatillah, Rahmawati Fitriyanti, Ali Wafa \\ UIN Sunan Ampel, Surabaya - Indonesia | nailaafifarohmatillah@gmail.com
}

\begin{abstract}
Abstrak: Pendidikan merupakan salah satu hal penting sehingga mendorong pemerintah untuk terus meningkatkan kualitas layanan pendidikan. Salah satu upaya untuk meningkatkan dan pemerataan kualitas pendidikan di Indonesia yaitu dengan diaplikasikannya sistem zonasi terhadap proses penerimaan peserta didik baru. Ketentuan sistem zonasi dimuat dalam Permendikbud Nomor 14 Tahun 2018. Penelitian ini menggunakan penilitian deskriptif dengan pendekatan kualitatif. Disebut penelitian deskriptif karena bertujuan untuk menggambarkan atau mendeskripsikan keadaan suatu obyek dan subjek penelitian. Dilihat dari besarnya jumlah peminat yang masuk ke MTs Nurul Huda dan dari sudut prestasi, MTs Nurul Huda dapat dikategorikan sebagai salah satu madrasah yang memiliki daya saing tinggi. Salah satunya yaitu kepimpinan kepala sekolah yang efektif dan inovatif, sarana yang memadai, kualitas pendidik yang memenuhi standar dan dikembangkannya berbagai inovasi pembelajaran. Dengan sistem zonasi ini MTs. Nurul Huda tahun ini telah memaksimalkan kekuatan madrasah untuk memberikan kepercayaan kepada masyarakat dan membuat MTs. Nurul Huda ini lebih unggul dari sekolah lain.
\end{abstract}

Keywords: madrasah berkualitas dan sistem zonasi.

\section{Pemdahuluan}

Pendidikan merupakan hak asasi manusia sehingga memiliki peran penting dalam kehidupan bermasyarakat. Seperti yang tertera dalam pasal 31 ayat (1) Undang-Undang Dasar 1945 yang menyebutkan bahwa : setiap warga negara berhak mendapat pendidikan. Pelaksanaan proses pendidikan ini guna mencerdaskan dan mengembangkan moral bangsa agar menjadi lebih baik dan bermartabat. Pendidikan adalah salah satu hal penting sehingga 
mendorong pemerintah untuk terus meningkatkan kualitas layanan pendidikan.

Madrasah dikatakan berkualitas, jika sistem pengelolaannya ditangani oleh pemimpin yang memiliki kinerja yang baik dan komitmen terhadap apa yang telah diprogramkan. Pernyataan ini tentunya merupakan sebuah sistem yang saling menopang satu sama lain dalam perspektif manajerial kepemimpinan. Kepala sekolah dalam konteks ini sebagai power figure harus mampu memenej secara professional, sehingga terjadi interaksi komunikatif-baik dalam perspektif-proses pembelajaran maupun sistem birokrasi dan 2 administrasi madrasah yang tertib. Ekspresi ini sesuai dengan UU No. 20 Tentang Sisdiknas, Pasal 39 ayat (1) bahwa "Tenaga kependidikan bertugas melaksanakan administrasi, pengelolaan, pengembangan, pengawasan, dan pelayanan teknis untuk menunjang proses pendidikan pada satuan pendidikan". Artinya kepala sekolah sebagai motor di dalam meningkatkan kualitas madrasah.

Kualitas layanan pendidikan dapat ditunjukan dengan peningkatan mutu pendidikan dan pembaharuan sistem pendidikan. Peningkatan layanan pendidikan merupakan salah satu faktor penting untuk mewujudkan pendidikan yang berkualitas. Salah satu upaya dalam meningkatkan kualitas pendidikan yaitu dengan melalui pemerataan pendidikan. Perbaikan sistem pendidikan nasional dapat dilakukan melalui peningkatan kualitas secara umum dan menyeluruh maupun secara khusus bagi sekolahsekolah agar bisa memiliki kesetaraan kualitas. Undang-undang Nomor 20 Tahun 2003 tentang Sistem Pendidikan Nasional pasal 1 ayat (3) menjelaskan bahwa "Sistem pendidikan nasional adalah keseluruhan komponen pendidikan yang saling terkait secara terpadu untuk mencapai tujuan pendidikan nasional". Terkait dengan sistem pendidikan, saat ini telah dilakukan pembaharuan terhadap sistem pendidikan, yaitu dengan melakukan sistem zonasi pada saat pelaksanaan Penerimaan Peserta Didik Baru (PPDB). Sistem ini diterapkan dalam PPDB mekanisme luar jejaring (luring/offline) dan dalam jejaring (daring/online). 
Salah satu upaya untuk peningkatan dan pemerataan kualitas pendidikan di indonesia yaitu dengan diaplikasikannya sistem zonasi pada Penerimaan Peserta Didik Baru tahun 2018. Ketentuan sistem zonasi yang dimuat dalam PPDB tahun 2018 ini berdasarkan pada Permendikbud Nomor 14 Tahun 2018 yang bertujuan menjamin peneimaan peserta didik baru berjalan dengan objektif, akuntabel, transparan dan tanpa diskriminasi sehingga mendorong peningkatan akses layanan pendidikan

Sistem zonasi merupakan sistem penerimaan peserta didik baru yang diberlakukan dengan penentuan radius zona oleh pemerintah daerah masing-masing dan Sekolah wajib menerima calon peserta didik yang berdomisili pada radius zona terdekat dengan persentase tertentu dari total jumlah peserta didik yang akan diterima. Sistem zonasi yang merupakan rekomendasi dari Ombudsman Republik Indonesia pada tahun 2016 kepda Kemendikbud, Kemendagri, dan Kemenag ini kemudian dilaksanakan olen Menteri Pendidikan dan Kebudayaan Muhadjir Effendy dengan tujuan untuk menghilangkan predikat sekolah favorit dan tidak favorit, agar tercipta pemerataan kualitas pendidikan diseluruh sekolah di Indonesia.

\section{Metodologi}

Pendekatan penelitian yang digunakan dalam penelitian ini adalah penilitian deskriptif dengan pendekatan kualitatif. Disebut penelitian deskriptif karena bertujuan untuk menggambarkan atau mendeskripsikan keadaan suatu obyek dan subjek penelitian. Menurut Sugiono menyebutkan metode penelitian kualitatif adalah penelitian yang dilakukan pada kondisi alamiah atau natural setting.

Fokus dalam melakukan sebuah penelitian perlu ditentukan. Hal ini dilakukan agar suatu penelitian tidak menyimpang dari tujuan penelitian yang telah di tetapkan. Dalam penelitian kualitatif, fokus penelitian ini digunakan untuk mengetahui batasan-batasan dalam penelitian untuk menyelesaikan masalah dalm penelitian. Untuk itu, fokus penelitian ini adalah mengetahui pengelolaan 
madrasah yang berkualitas dan penyebab sistem zonasi bagi MTs. Nurul Huda Sedati.

Subyek dalam penelitian ini adalah orang-orang yang dianggap mengetahui dan memahami hal-hal terkait dengan fokus penelitan. Sehingga mampu memberikan informasi yang di perlukan. Adapun yang menjadi subyek penelitian antara lain adalah bapak Imam selaku bagian waka kurikulum di MTs Nurul Huda Sedati. Teknik pengumpulan data dilakukan melalui observasi dan wawancara.

\section{Hasil dan Pembahasan}

\section{Madrasah yang Berkualitas}

Dalam perjalanan sejarah masa lalu hingga masa kini, bangsa Indonesia telah mengenal berbagai lembaga pendidikan, baik lembaga pendidikan sekuler maupun lembaga pendidikan Islam. Khusus lembaga pendidikan Islam terdapat berbagai macam lembaga pendidikan, antara lain Masjid, Surau, Dayah, Pesantren, Majlis Ta'lim, dan Madrasah yang masing masingnya memiliki karakter dan kekhasan tersendiri. Madrasah, di samping memiliki sejarah yang cukup panjang juga memiliki keunikan tersendiri. Ada berbagai jenis madrasah antara lain: Madrasah Negeri, Madrasah Swasta, Madrasah Model, Madrasah Terpadu, Madrasah Wajib Belajar, Madrasah Unggulan, Madrasah Aliayah Keagamaan, Madrasah Program Berketerampilan Khusus, dan lain sebagainya.

Sebagai lembaga pendidikan Islam, madrasah mengalami pasang surut sedemikian rupa, terutama dilihat dari kedudukannyadi banding dengan lembaga pendidikan umum. Sebelumnya madrasah merupakan lembaga pendidikan kelas dua sebagai subsistem pendidikan nasional. Namun semenjak lahirnya Undang-undang No. 2 Tahun 1989 tentang Sistem Pendidikan Nasional, madrasah memiliki kedudukan yang sama dengan lembaga pendidikan umum pada umumnya. Madrasah adalah sekolah umum berciri khas agama Islam. Madrasah Ibtidaiyah sama dengan SD, Madrasah Tsanawiyah sama dengan SMP, dan Madrasah Aliyah sama dengan SMA. Tamatan Ibtidaiyah dapat melanjutkan ke SMP, tamatan Madrasah Tsanawiyah dapat melanjutkan ke SMA, dan dengan demikian sebaliknya, yang pada masa-masa sebelumnya tidak seperti itu. Dengan kata lain 
sebenarnya madrasah itu adalah sekolah umum plus. Dari sisi ini, sebenarnya madrasah memiliki modal yang lebih baik atau lebih maju dibanding dengan sekolah umum untuk menjadikan dirinya bermutu.

Bagaimana dengan mutu madrasah? Berbicara tentang mutu madrasah tentu sangat berkaitan erat dengan berbagai hal. Salah satunya adalah berkaiatan dengan system, yang berlaku tidak saja bagi madrasah, tetapi berlaku juga bagi semua lembaga pendidikan, baik lembaga pendidikan Islam maupun lembaga pendidikan umum pada umumnya. Sistem tersebut meliputi berbagai sub sistem, mulai dari input, proses, output, maupun outcome. Untuk mewujudkan sekolah/madrasah bermutu, terdapat banyak konsep/teori yang dapat dijadikan rujukan atau pedoman, baik dari nilainilai ajaran Islam itu sendiri, atau dari teori-teori yang ditemukan dan dikembangkan oleh para ahli manajemen mutu.

Menurut Danim kualitas pendidikan tidak semata-mata diukur dari mutu keluaranpendidikan secara utuh (educationoutcomes) akan tetapi dikaitkan dengan konteks di mana mutu itu ditempelkan dan berapa besar persyaratan tambahan yang diperlukan untuk itu. Misalnya, seorang lulusan Madrasah Aliyah untuk menduduki dunia kerja tidak perlu mendapatkan pelatihan tambahan sebelum memberikan layanan di tempat kerjanya, berarti ia adalah lulusan yang lebih bermutu daripada yang masih harus menempuh pelatih pra penempatan dengan spesifikasi yang sama. Kualitas pendidikan juga bisa diukur dari besarnya kapasitas layanan pendidikan dalam memenuhi customers needs dikaitkan dengan besarnya pengorbanan yang diperlukan untuk itu, seperti biaya yang dikeluarkan oleh masyarakat atau pemerintah, lama belajar, dan biaya-biaya tidak langsung.

Kehadiran PP No. 19/2005 tentang Standar Nasional Pendidikan (SNP) patut disyukuri, karena dapat berfungsi sebagai dasar dalam perencanaan, pelaksanaan, dan pengawasan pendidikan dalam rangka mewujudkan pendidikan nasional yang berkualitas melalui Badan Akreditasi Nasional Sekolah/Madrasah. Kualitas pendidikan dapat dilihat dari isi, proses, kompetensi lulusan, pendidik dan tenaga kependidikan, sarana dan prasarana, pengelolaan, 
pembiayaan, dan penilaian pendidikan. Untuk melaksanakan ketentuan perundang-undangan yang berlaku tersebut hendaknya dimulai dengan upaya membangun komitmen bersama dan diorientasikan pada peningkatan kualitas Sumber Daya Manusia yang terlibat di dalamnya.

Sedangkan madrasah berkualitas/unggul adalah Madrasah yang dikembangkan untuk mencapai keunggulan dalam keluaran (output) pendidikannya. Untuk mencapai keunggulan tersebut maka masukan (input), proses pendidikan, guru dan tenaga kependidikan, manajemen, layanan pendidikan, serta sarana penunjangnya harus diarahkan untuk menunjang tercapainya tujuan tersebut. Sedangkan dalam Permendik-nas No.63 tahun 2009, dijelaskan bahwa, Mutu pendidikan adalah tingkat kecerdasan kehidupan bangsa yang dapat diraih dari penerapan Sistem Pendidikan Nasional. Selanjutnya dalam Pasal 10 ayat 1 dan ayat 2 disebutkan bahwa penjaminan mutu pendidikan oleh satuan atau program pendidikan ditujukan untuk memenuhi tiga tingkatan acuan mutu, yaitu: SPM, SNP, Strandar mutu pendidikan di atas SNP.

Ciri-ciri madrasah berkualitas/unggul dan berkarakter Dimensidimensi keunggulan sebagai ciri madrasah unggul, adalah sebagai berikut.

Masukan (input) yaitu siswa diseleksi secara ketat dengan menggunakan kriteria tertentu dan prosedur yang dapat dipertanggungjawabkan. Kriteria yang dimaksud adalah: prestasi belajar superior dengan indikator angka rapor, Nilai Ebtanas Murni (NEM), dan hasil tes prestasi akademik, skor psikotes yang meliputi inteligensi dan kreativitas, tes fisik, jika diperlukan.

Sarana dan prasarana yang menunjang untuk memenuhi kebutuhan belajar siswa serta menyalurkan minat dan bakatnya, baik dalam kegiatan kurikuler maupun ekstra kurikuler.

Lingkungan belajar yang kondusif untuk berkembangnya potensi keunggulan menjadi keunggulan yang nyata baik lingkungan fisik maupun sosial-psikologis. 
Guru dan tenaga kependidikan yang menangani harus unggul baik dari segi penguasaan materi pelajaran, metode mengajar, maupun komitmen dalam melaksanakan tugas.

Kurikulumnya diperkaya dengan pengembangan dan improvisa-si secara maksimal sesuai dengan tuntutan belajar peserta didik yang memiliki kecepatan belajar serta motivasi belajar yang lebih tinggi dibanding dengan siswa seusianya.

Kurun waktu belajar lebih lama dibandingkan sekolah lain. Karena itu perlu ada asrama untuk memaksimalkan pembinaan dan menampung para siswa dari berbagai lokasi. Di kompleks asrama perlu ada sarana yang bisa menyalurkan minat dan bakat siswa seperti perpustakaan, alat-alat olah raga, kesenian dan lain-lain yang diperlukan.

Proses belajar mengajar harus berkualitas dan hasilnya dapat dipertanggungjawabkan (accountable) baik kepada siswa, lembaga, maupun masyarakat.

Sekolah unggul tidak hanya memberikan manfaat kepada peserta didik di sekolah tersebut, tetapi harus memiliki resonansi sosial kepada lingkungan sekitarnya.

Nilai lebih sekolah unggul terletak pada perlakuan tambahan di luar kurikulum nasional melalui pengembangan kurikulum, program pengayaan dan perluasan, pengajaran remidial, pelayanan bimbingan dan konseling yang berkualitas, pembinaan kreativitas dan disiplin.

Menurut Purkey dan Smith mengidentifikasi sembilan karakteristik yang bersifat organisasi dan empat karakteristik yang bersifat proses, yaitu :

- Karakteristik yang bersifat organisasi adalah :

- Manajemen berbasis sekolah (School site management)

- Kepemimpinan instruksional (instructional leadership)

- Kestabilan staf (staff stability)

- Kurikulum yang jelas dan pengorganisasian (curriculum articulation and organization)

- Pengembangan staf pada lingkup sekolah (school wide staff development) 
- Keterlibatan dan dukungan orang tua (parental involvement and support)

- Penghargaan/pengakuan keberhasilan akademik pada lingkup sekolah (school wide recognition of academic success)

- Memaksimalkan waktu belajar (maximized learning time)

- Dukungan kantor distrik (district support)

- Karakteristik yang bersifat adalah :

- Perencanaan bersama dan hubungan yang bersahabat (collaboration planning and collegial relationship)

- Perasaan sebagai satu komunitas (sense of community)

- Tujuan akhir yang jelas dan harapan yang tinggi (clear goals and high expextation)

- Tertib dan disiplin (order and discipline).

Jadi, madrasah berkualitas/unggul dan berkarakter memiliki indikator yaitu Perumusan visi, misi dan target mutu yang jelas dipahami semua pihak yang terlibat pimpinan, guru, karyawan peserta didik,orang tua dan komite sekolah/madrasah, kepemimpinan sekolah yang kuat, memperoleh dukungan dari semua pihak terkait, memiliki motivasi dan harapan prestasi yang tinggi, mampu bersaing secara terus menerus, pengembangan dan pelatihan tenaga pendidik dan kependidikan sekolah yang terencana secara terus-menerus, evaluasi hasil belajar dan faktorfaktor yang mempengaruhinya untuk penyempurnaan proses pembelajaran, komunikasi dan dukungan orang tua dan masyarakat, komitmen seluruh warga sekolah akan pentingnya peningkatan mutu, lingkungan sekolah yang aman dan tertib, membangun jaringan kerjasama dengan pihak terkait secara terusmenerus.

Selanjutnya dalam pelaksanaannya, madrasah perlu mendapat dukungan daei beberapa unsur pokok yang harus terpenuhi. Idealnya madrasah memiliki performansi yang sebanding lurus dengan amanah yang diembannya guna memenuhi harapan dan kepercayaan dari stakholders, orang tua, siswa, masyarakat dan pemerintah. 
Menurut Imron Arifin, unsur pendukung madrasah itu setidaknya ada sembilan faktor, yaitu :

Faktor sarana dan prasarana meliputi fasilitas sekolah yang lengkap dan memadahi, sumber belajar yang memadai dan sarana penunjang belajar yang memadahi.

Faktor guru meliputi tenaga guru mempunyai kualifikasi memadahi, kesejahteraan guru terpenuhi, rasio guru-murid ideal, loyalitas dan komitmen tinggi, dan motivasi dan semangat kerja guru tinggi.

Faktor murid meliputi pembelajaran yang terdiferensiasi, kegiatan intra dan ekstrakulikuler bervariasi, motivasi dan semangat belajar tinggi, pemberdayaan belajar bermakna.

Faktor tatanan organisasi dan mekanisme kerja mliputi tatanan organisasi yang rasional dan relevan, program organisasi yang rasional dan relevan, mekanisme kerja yang jelas dan terorganisasi secara tepat.

Faktor kemitraan meliputi kepercayaan dan harapan orangtua tinggi, dukungan dan peran serta masyarakat tinggi, dukungan dan bantuan pemerintah tinggi.

Faktor komitmen/sistem nilai meliputi budaya lokal yang saling mendukung, nilai-nilai agama yang memicu timbulnya dukungan positif.

Faktor motivasi, iklim kerja, dan semangat kerja meliputi motivasi berprestasi pada semua komunitas sekolah, suasana, iklim kerja dan iklim belajar sehat dan positif, dan semangat kerja dan berprestasi tinggi.

Faktor keterlibatan Wakil Kepala sekolah dan guru-guru meliputi keterwakilan kepala sekolah dalam pembuatan kebijakan dan pengimplementasiannya, keterwakilan kepala sekolah dan guru-guru dalam menyusun kurikulum dan program-program sekolah, dan keterlibatan wakil kepala sekolah dan guru-guru dalam perbaikan dan inovasi pembelajaran.

Faktor kepemimpinan kepala sekolah meliputi piawai memanfaatkan nilai religio-kultural, piawai mengkomunikasikan visi, inisiatif, dan kreativitas, piawai menimbulkan motivasi dan membangkitkan semangat, piawai memperbaiki pembelajaran yang 
terdiferensiasi, piawai menjadi pelopor dan teladan, dan paiwai mengelola administrasi sekolah.

\section{Dampak Sistem Zonasi Bagi MTs Nurul Huda Sedati}

Menurut Kamus Besar Bahasa Indonesia (KBBI) Sistem zonasi adalah sebuah sistem pengaturan proses penerimaan siswa baru sesuai dengan wilayah tempat tinggal. Sistem tersebut diatur dalam Permendikbud Nomor 14 Tahun 2018 dan ditujukan agar tak ada sekolah-sekolah yang dianggap sekolah favorit dan non-favorit. Secara keseluruhan sistem zonasi yang berlaku saat ini merupakan landasan pokok penataan reformasi sekolah mulai dari Taman Kanak-kanak (TK) hingga Sekolah Menengah Atas (SMA). Sistem Zonasi yg mengatur mengenai zona wilayah bagi calon siswa dimuat dalam Sistem PPDB yang baru melalui Permendikbud No.14 Tahun 2018. Sistem zonasi terbaru ini prinsip nya Hampir sama dengan Sistem Bina lingkungan, hanya saja pada jumlah kuota sistem zonasi ini jauh lebih bnyak dibandingkan bina lingkungan yaitu mencapai $90 \%$.

Sistem zonasi PPDB merupakan kebijakan yang telah berjalan sejak tahun 2017, yang dimaksudkan untuk pemerataan kualitas pendidikan, yang diharapkan dapat menghilangkan dikotomi sekolah unggulan dan non-unggulan. Perbedaan sistem zonasi tahun ini dengan tahun 2017, sistem zonasi tahun ini diberlakukan ke seluruh sekolah yang diselenggarakan pemerintah daerah. Sedangkansistem zonasi PPDB 2017 masih tahap adaptasi sehingga dalam praktiknya belum semua sekolah menerapkan sistem ini.

Ketentuan Dalam Sistem Zonasi :

Didalam sistem zonasi, sekolah yang diselenggarakan oleh pemerintah daerah wajib menerima calon peserta didik berdomisili pada radius zona terdekat dari Sekolah dengan persentase minimal sebesar $90 \%$ (sembilan puluh persen) dari total jumlah keseluruhan peserta didik yang diterima.

Domisili calon peserta didik berdasarkan alamat pada kartu keluarga yang diterbitkan paling lambat 6 (enam) bulan sebelum pelaksanaan PPDB, tujuan nya adalah untuk memastikan radius zona terdekat calon peserta didik terhadap suatu sekolah. 
Dalam hal radius zona terdekat, ditetapkan oleh pemerintah daerah sesuai dengan kondisi di daerah berdasarkan ketersediaan anak usia Sekolah didaerah tersebut dan jumlah ketersediaan daya tampung dalam rombongan belajar pada masing-masing Sekolah.

Dalam menetapkan radius zona pemerintah daerah dalam hal ini dinas pendidikan dan kebudayaan melibatkan musyawarah/kelompok kerja bersama kepala Sekolah ataupun instansi terkait.

Untuk Proses Penerimaan Calon Peserta didik yg berdomisili diluar radius zona dapat menggunakan jalur prestasi dengan kuota sebanyak 5\% dari jumlah yg akan diterima. Ataupun calon peserta didik yg melakukan perpindahan domisili dengan alasan khusus dapat menggunakan jalur perpindahan domisili sebesar 5\% dari jumlah yg akan diterima. Artinya Sistem Zonasi ini memberikan $90 \%$ kuota terhadap calon peserta didik dengan radius zona terdekat dan $10 \%$ diluar penerimaan melalui radius zona terdekat.

Siswa baru yang diterima melalui PPDB zonasi memang tinggal lebih dekat dengan sekolah negeri dibanding PPDB berbasis prestasi. Namun komposisi siswa yang diterima melalui sistem zonasi memiliki nilai rendah dan lebih beragam dibandingkan dengan siswa yang diterima melalui sistem prestasi. Keadaan ini menuntut guru-guru di sekolah negeri untuk beradaptasi dengan cepat.

Para guru yang terbiasa mengajar siswa dengan kemampuan rata-rata tinggi, kini harus mengajar siswa dengan nilai rata-rata rendah dengan kemampuan yang sangat beragam. Padahal, keterampilan yang dibutuhkan oleh guru yang mengajar anak-anak berkemampuan tinggi dan berkemampuan rendah berbeda. Anakanak berkemampuan tinggi membutuhkan tantangan baru dan pengayaan dari guru agar bisa termotivasi dan meningkatkan kemampuannya. Di sisi lain, anak-anak berkemampuan rendah membutuhkan bantuan guru untuk membangun pemahaman ilmunya dengan benar.

Terlebih lagi, tantangan guru dalam mengajar anak dengan kemampuan beragam lebih berat daripada anak dengan kemampuan yang relatif homogen. Guru yang mengajar kelas yang 
homogen cenderung dapat mengajarkan seluruh siswa dengan seiring sejalan. Namun, ketika kelas yang diajar relatif heterogen, guru harus menyesuaikan pola mengajar untuk mengakomodasi anak yang cepat dan lambat dalam belajar. Semakin besar kesenjangan kemampuan anak, semakin besar beban guru dalam mengajar.

Masalahnya, penyesuaian kemampuan guru mengajar ini tidak bisa dilakukan dalam waktu singkat. Alhasil, proses pembelajaran di kelas tidak bisa berjalan secara optimal dan menciptakan kekagetan yang justru mengganggu proses belajar di kelas. Terlepas dari masalah yang dihadapi guru, siswa pun mengalami tantangan akibat komposisi kelas yang heterogen. Siswa yang lambat dalam belajar bisa tertinggal dari teman-temannya dan menjadi tidak nyaman dalam belajar. Kemudian, siswa yang cepat dalam belajar dapat kehilangan motivasi jika tidak mendapatkan tantangan.

Jika dilihat secara geografis, data lokasi sekolah di Madrasah kita menunjukkan bahwa sekolah negeri tidak tersebar secara merata jika dibandingkan dengan persebaran tempat tinggal calon siswa. Dalam PPDB zonasi, kondisi ini merugikan calon peserta didik yang domisilinya relatif jauh dengan sekolah negeri disekitarnya.Satu-satunya peluang lain bagi calon siswa tersebut untuk terdaftar di sekolah negeri adalah dengan mengejar kuota jalur prestasi yang paling banyak hanya $5 \%$ dari total kuota.

Meski sekolah swasta tidak diwajibkan mengikuti sistem PPDB zonasi, sekolah swasta terpapar dampak tidak langsung dari perubahan di sekolah negeri. Sekolah swasta yang letaknya berdekatan dengan beberapa sekolah negeri dan tidak berada pada perumahan padat penduduk akan merugi karena mereka berpotensi kehilangan calon siswa dalam jumlah besar. Di sisi lain, sekolah swasta dengan kualitas yang relatif baik akan diuntungkan karena berpotensi menerima lebih banyak pendaftar dengan capaian kemampuan tinggi yang tidak diterima di sekolah negeri akibat sistem PPDB zonasi.

Sistem zonasi yang diterapkan menimbulkan 2 kondisi yaitu anak yang tinggal di dekat sekolah mempunyai peluang lebih besar untuk diterima, meskipun nilai US/MBD-nya tidak memenuhi 
standar dan sekolah yang mengutamakan pelamar yang memiliki nilai US/MBD sehingga mereka yang kurang nilainya meskipun tinggal di sekitar sekolah dapat diterima. Akibatnya calon peserta didik yang kurang nilainya harus melamar di sekolah swasta atau sekolah negeri lain yang lebih jauh dari tempat tinggalnya. Sistem zonasi akan menguntungkan calon peserta didik yang tinggal dekat dengan sekolah.

Hal ini sesuai dengan cita-cita Menteri Muhadjir agar mengurangi waktu tempuh peserta didik ke sekolah. Mekipun tidak berprestasi, calon pesertadidik dapat melanjutkan pendidikan disekolah yang terdekat dengan domisilinya. Di sisi lain, sistem zonasi membuat calon peserta didik yang berprestasi didorong untuk mendaftar pada sekolah yang terdekat meskipun bukan sekolah dengan kualitas terbaik. Hal ini merupakan harapan Menteri Muhadjir agar dapat menghapus sekolah favorit, semua sekolah sama dengan fasilitasnya. Padahal,pemerintah belum mampu menghapus disparitas kualitas antar sekolah, sehingga pasti ada sekolah dengan sumber daya yang lebih dibandingkan sekolah lain.

Sistem zonasi menyebabkan berkumpulnya peserta didik dengan kemampuan yang beragam dalam satu sekolah, bahkan satu kelas. Mereka yang tidak berprestasi dan yang berprestasi dapat menjadi satu rombel. Hal ini akan memengaruhi proses pembelajaran peserta didik. Penelitian menemukan bahwa prestasi peserta didik tidak hanya bergantung pada dirinya saja, tapi juga lingkungan pembelajaran. Rimm menyatakan bahwa pesertadidik dapat mengalami kurang berprestasi yaitu ketimpanganantara performa akademik di sekolah dan indeks kemampuan anak. Jika anak tidak bekerj sesuai dengan kemampuannya di sekoah, maka mereka menjadi kurang berprestasi.

Adapun dampak dari sistem zonasi bagi MTs Nurul Huda Sedati yaitu membuat stakeholder mulai dari kepala madrasah beserta tenaga pendidik bekerja extra keras untuk meningkatkan kualitas pendidikan, kualitas guru, kualitas manajemen, kualitas kegiatan siswa, pembiasaan siswa. dan dengan adanya sistem 
zonasi ini pihak madrasah harus meningkatkan mutu pendidikan yang lebih baik. Pada sistem zonasi ini sangat menguntungkan bagi madrasah khususnya pada lingkup swasta. Pada dasarnya siswasiswi dan orang tua sangat berminat untuk mendaftarkan anaknya ke sekolah berbasis negeri, akan tetapi dengan adanya sistem zonasi masyarakat akan mengetahui keunggulan-unggulan yang ada pada sekolah swasta karena dengan adanya sistem zonasi ini madrasah memberikan kepercayaan kepada masyarakat bahwa masdrasah tersebut lebih unggul proses pembelajaran dari negeri bahkan hasil output dari madrasah lebih unggul. Sistem zonasi ini sangat memicu sekolah swasta untuk memberikan kesempatan untuk meningkatkan kepercayaan masyarakat dan lebih terorganisir.

Kelebihan dari kegiatan MTs. Nurul Huda yaitu kebiasaan sholat dhuha, full day school, BTQ BMQ serta mengoptimalkan dan memaksimalkan kegiatan pembiasaan siswa, menambahkan kegiatan-kegiatan positif yang menjadi tuntutan anak-anak dan juga dari segi pendukug utama yaitu dari sumber daya yang unggul, sarana prasarana akademik yang representatif dan fasilitas penunjang internalisasi nilai keislaman yang unggul.

Jadi dari pihak orang tua yang mengetahui sistem zonasi tidak akan terpengaruh adanya sistem ini karenaorang tua telah mengetahui keungglan-keunggulan madrasah yang tidak berbasis negeri. Dengan sistem zonasi ini MTs. Nurul Huda tahun ini telah memaksimalkan kekuatan madrasah untuk memberikan kepercayaan kepada masyarakat. Jadi dapat diakui bahwa tidak hanya sekolah negeri saja yang mempunyai keunggulan akan tetapi madrasah yang berbasis swasta pun mempunyai keunggulan yang lebih baik dari sekolah negeri.

\section{Kesimpulan}

Dilihat dari besarnya jumlah peminat yang masuk ke MTs Nurul Huda dan dari sudut prestasi, MTs Nurul Huda dapat dikategorikan sebagai salah satu madrasah yang memiliki daya saing tinggi. Faktor-faktor yang mendukung daya saing madrasahadalah adanya kepimpinan kepala sekolah yang efektif dan inovatif, sarana yang memadai, kualitas pendidik yang 
memenuhi standar dan dikembangkannya berbagai inovasi pembelajaran. Berbagai faktor ini telah menjadi pendorong dan daya tarik masyarakat untuk menyekolahkan anak-anak mereka di madrasah ini.

Dengan sistem zonasi ini MTs. Nurul Huda tahun ini telah memaksimalkan kekuatan madrasah untuk memberikan kepercayaan kepada masyarakat. Jadi dapat diakui bahwa tidak hanya sekolah negeri saja yang mempunyai keunggulan akan tetapi madrasah yang berbasis swasta pun mempunyai keunggulan yang lebih baik dari sekolah negeri. Bahwa sistem zonasi juga merupakan upaya mencegah penumpukan sumber daya manusia yang berkualitas dalam suatu wilayah tertentu dan mendorong pemerintah daerah serta peran serta masyarakat dalam pemerataan kualitas pendidikan sesuai amanat Undang-Undang Sistem Pendidikan Nasional (Sisdiknas). Sistem zonasi dapat menghadirkan populasi kelas heterogen, sehingga akan mendorong kreativitas pendidik dalam pembelajaran di kelas. Populasi yang ada di dalam sebuah kelas harus heterogen. Salah satu arahkebijakan zonasi ini adalah meningkatkan keragaman peserta didik di sekolah, sehingga nantinya akan menumbuhkan miniaturminiatur kebinekaan di sekolah.

Berdasarkan hasil kesimpulan yang telah diuraikan sebelumnya, maka peneliti memberikan beberapa saran terkait kualitas madrasah terhadap sistem zonasi yaitu akan lebih baik jika madrasah mempertahankan kualitas madrasah yang dapat memberikan kepercayaan kepada masyarakat bahwa MTs Nurul Huda lebih unggul dalam proses pembelajaran dari sekolah Negeri dan hasil output madrasah lebih unggul. Sistem zonasi ini sangat memicu sekolah swasta untuk memberikan kesempatan untuk meningkatkan kepercayaan masyarakat yang lebih terorganisir.

\section{References}

Reza, Eka (2019): "Implementasi Kebijakan Sistem Zonasi Terhadap Proses Penerimaan Peserta Didik Baru Kabupaten Lampung 
Tengah". Fakultas Hukum Universitas Lampung. Universitas Lampung.

Mustaqim, (2012): "Sekolah/Madrasah Berkualitas Dan Berkarakter". IAIN Walisongo Semarang.

Tholkhah, Imam (2016): “Strategi Peningkatan Daya Saing Madrasah; Studi Kasus Madrasah Ibtidaiyah Negeri Madiun. Jakarta Pusat, Puslitbang Pendidikan Agama dan Keagamaan Badan Litbang dan Diklat Kemenag RI.

Saleh, Abdul Rahman (2004): Madrasah dan Pendidikan Anak Bangsa. Jakarta, Raja Grafindo Persada.

Yatim, Badri dkk. (2000): Sejarah Perkembangan Madrasah. Jakarta, Departemen Agama RI Direktorat Jenderal Pembinaan Kelembagaan Agama Islam.

Umaedi, 2004, Manajemen Mutu Berbasis Sekolah/ Madrasah (MMBS/M), Jakarta: Pusat Kajian Manajemen Mutu Pendidikan. 